\title{
Dental treatment needs in patients of a Lublin dental clinic aged 35-54
}

\begin{abstract}
Introduction. Evaluation of the oral health among adult Poles carried out in the framework of the "National Monitoring of Oral Health and Its Determinants" study and the research results of clinical centers in Poland indicate that dental caries, periodontal diseases and missing teeth are a major health problem.

Aim. The aim of the study was determining the reasons for reporting to the dentist of 35-54-year-old people, the assessment of dental health and prosthetic needs.

Material and methods. The study comprised 154 patients aged 35-54 reporting in 2015 to the dental clinic in Lublin, which offers treatment financed by the National Health Fund or for a fee. Gender, age, the place of residence and the reason for the reporting to the dentist were analyzed. The place of residence was a village, a town of less than 200 thousand inhabitants or the city of more than 200 thousand residents. The reason for reporting to the dental clinic was a check-up visit, toothache or loss of filling. Dental condition was assessed by calculating the DMF index. The prosthetic state and needs were evaluated. The results were statistically analyzed.

Results. Most patients reporting to the dental examination were women (59.09\%) and residents of a big city (70.78\%). More than a half of the patients (55.84\%) had a check-up appointment, 25.32\% appeared due to the loss of filling, and 18.83\% - because of a toothache. The frequency of decay in the study group was $100 \%$ and the DMF index values ranged from 2.0 to 32.0 , assuming an average of $21.18 \pm 5.02$, and with the age the DMF index values increased. The highest number of decayed and extracted teeth were found in the rural population. Both residents of big cities and patients who reported for regular check-ups had the biggest number of fillings.

Conclusion. Dental caries is still a major health problem in Polish population aged 35-44. Poor oral health among the adult population in Poland is due to the low health awareness of society. This requires launching large-scale dental educational campaigns and prevention measures among adult Polish citizens, especially in rural areas.
\end{abstract}

Keywords: oral health, treatment needs, adults, Poland.

DOI: $10.1515 /$ pjph-2016-0029

\section{INTRODUCTION}

The World Health Organization (WHO) defines health as "complete physical, mental and social wellbeing, and not only the absence of disease or infirmity." Proper dental and periodontal health significantly affects the overall health of an individual. In the last thirty years, quality of life associated with oral health has gained great importance (Oral Health Related Quality of Life). The presence of cavities, missing teeth, and the use of prosthetic restorations greatly reduces this quality [1].

In response to the problems concerning the state of the oral cavity, in 2013 the Polish Minister of Health launched a program „Monitoring of the state of oral health of Polish population in 2013-2015." This is one of the elements of the "National Monitoring of Oral Health and Its Determinants", introduced in 1997. Its aim is to assess the oral health of children and adults, and to examine the impact of social, economic, organizational and cultural factors on the condition of the oral cavity [2].

The results obtained in the course of the program and the studies carried out in clinical centers across the country have shown that tooth decay affects nearly all adults in Poland. Moreover, periodontal diseases remain a growing problem, which more often leads to loss of teeth. This reflects the relatively low health awareness concerning the maintenance of healthy teeth and periodontium. With age, also the number of missed teeth increases boosting the number of patients using prosthetic restorations [3-7].

\footnotetext{
${ }^{1}$ Chair and Department of Paedodontics, Medical University of Lublin, Poland

${ }^{2}$ Chair and Department of Conservative Dentistry with Endodontics, Medical University of Lublin, Poland

${ }^{3}$ Department of Prosthetics, Medical University of Lublin, Poland

${ }^{4}$ Department of Mathematics and Biostatistics, Medical University of Lublin, Poland
} 


\section{AIM}

The aim of the study was to determine the reasons for which people aged 35-54 reported to the dentist, as well as the assessment of their dental health and prosthetic needs.

\section{MATERIAL AND METHODS}

The study comprised 154 people aged 35-54. In 2015, they reported to a dental clinic located in Lublin. The practice offers treatment financed either through an agreement with the National Health Fund or for a fee. Gender, age, the place of residence and the reason for reporting to the dentist were analyzed. The respondents came from the following places: a village, a town of less than 200 thousand inhabitants or a city of more than 200 thousand inhabitants. They reported for a check-up visit, others due to a loss of filling or a toothache. Dental condition was assessed by calculating the DMF index. The status of dentition and the need for prosthetic treatment were assessed. The results were statistically analyzed using the Mann-Whitney test, Yates' Chi-squared test, KruskalWallis test, Spearman rank correlation test, Student's t test and one-way ANOVA test.

\section{RESULTS}

In the group of studied patients, women accounted for $59.09 \%(\mathrm{n}=91)$, men $-40.91 \%(\mathrm{n}=91)$. The average age was $42.83 \pm 5.42$ years, while the age of half of the patients did not exceed 43.0 years. The place of residence for $70.78 \%(n=109)$ of patients was a big city, a village - for $16.23 \%(\mathrm{n}=25)$, and a small town - for $12.99 \%(n=20)$ patients.

Most patients had a check-up - this means, 55.84\% ( $\mathrm{n}=86)$ of the study group. The loss of a filling was the reason for visiting dental clinic for $25.32 \%(n=39)$, and toothache for $18.83 \%(n=29)$ of the patients.

Among the patients studied, some $61.04 \%(\mathrm{n}=94)$ did not use any prosthetic restorations, while $23.38 \%(n=36)$ used a fixed denture, $12.34 \%(\mathrm{n}=19)$-removable denture, and $3.25 \%$ $(n=5)$ - used both the fixed and removable dental prostheses.

The number of teeth with decay (D) in the study group ranged from 0 to 15 . In half of them the number $\mathrm{D}$ was not higher than $3.0(\mathrm{Me}=3.0)$ and the average value was $3.71 \pm 3.25$. In 15 patients (9.74\% of all respondents), there was no presence of carious lesions, in the group of women $(8.79 \% ; n=8)$ and a group of men $(11.11 \% ; n=7)$, the observed differences were not statistically significant (Yates' $\mathrm{Chi}^{2}$ test $=0.040$; $\mathrm{p}=0.84$ ).

In women, the number $\mathrm{D}$ was ranging from 0 to 15.0 , in half of them it was higher than $3.0(\mathrm{Me}=3.0)$, and the average value was $3.84 \pm 3.19$. In men, the number $\mathrm{D}$ was ranging from 0 to 14.0, in half of them it did not exceed $2.0(\mathrm{Me}=2.0)$ and the average value was $3.52 \pm 3.34$. Gender of patients had no significant effect on the presence of carious lesions (MannWhitney $U$ test $Z=-1.02 ; p=0.31$ ).

A statistical analysis showed that in the study group the age of the patients did not influence significantly the value of $\mathrm{D}$ (test for Spearman's rank correlation coefficient $\mathrm{R}=-0.05$; $\mathrm{p}=0.53)$.

Among the respondents living in large cities the value $\mathrm{D}$ ranged from 0 to 14.0. In half of them it was not higher than $3.0(\mathrm{Me}=3.0)$, mean value $3.42 \pm 2.84$. In the group of the rural population, the number of decayed teeth ranged from 0 to 15 . In half of the patients it was not higher than $4.0(\mathrm{Me}=4.0)$, and the mean was at $5.12 \pm 4.51$. In patients from small towns, the value $\mathrm{D}$ ranged between 0 and 11.0, in half of them it did not exceed 3.0 $(\mathrm{Me}=3.0)$, and the average value was 3.50 3.19. Statistical analysis showed that the place of residence of the respondents had no significant effect on the value D (KruskalWallis $\mathrm{H}=2.08$; $\mathrm{p}=0.35$ ).

Among the patients reporting for check up visits, the value of $\mathrm{D}$ ranged between 0 and 15.0. In half of the respondents it was not higher than $2.0(\mathrm{Me}=2.0)$, and the average value was $3.17 \pm 3.41$. The value $\mathrm{D}$ in patients reporting due to loss of filling varied in the range between 1 and 10.0. In half of them it did not exceed 3.0 $(\mathrm{Me}=3.0)$, with the average value of $3.81 \pm 2.45$. In patients who reported to the dentist because of toothache, the value of $\mathrm{D}$ was ranging from 1.0 to 15.0 . The number of teeth affected by decay in half of the respondents in this group was higher than $4.0(\mathrm{Me}=4.0)$ and the average value $\mathrm{D}$ was $5.14 \pm 3.32$. The observed differences are statistically significant (Kruskal-Wallis test $\mathrm{H}=14.59$; $\mathrm{p}=0.0007$ ). The reason for reporting to the dentist has an impact on the value $\mathrm{D}$.

In the study group, $9.74 \%$ of the total study population $(n=15)$ had complete dentition. Women having complete dentition accounted for $7.69 \%(n=7)$, while men $12.70 \%(n=8)$. Gender of patients had no statistically significant effect on the incidence of missed teeth (Yates' $\mathrm{Chi}^{2}=0.57 ; \mathrm{p}=0.45$ ). The number of missed teeth (M) in the test ranged from 0 to 28.0 , in half of the patients it was not higher than 5.0 $(\mathrm{Me}=5.0)$, and assumed an average value of $6.88 \pm 6.47$. In women, the number $\mathrm{M}$ ranged from 0 to 28.0 , in half of them it was not higher than $6.0(\mathrm{Me}=6.0)$ and the average value was at $8.02 \pm 7.08$. In men, the number $M$ was in the range 0 to 20.0. In half of the respondents it did not exceed 3.0 $(\mathrm{Me}=3.0)$, with the average value of $5.24 \pm 5.10$. In women we observed higher number of missed teeth, and this difference is statistically significant (Mann-Whitney $\mathrm{Z}=-2.52 ; \mathrm{p}=0.012$ ).

A statistical analysis showed that the age of patients studied had a statistically significant impact on the value $M$ (test for the Spearman rank correlation coefficient $\mathrm{R}=0.56$; $\mathrm{p}=0.0001$ ). It was found that with age, the value $\mathrm{M}$ increases.

The place of residence had also a statistically significant impact on the number of missed teeth (Kruskal-Wallis test $\mathrm{H}=7.81 ; \mathrm{p}=0.02$ ). Statistical analysis shows that the highest values of $\mathrm{M}$ are confirmed in patients who live in a rural location in which the number of missed teeth was ranging from 1 to 28.0. In half of the respondents in this group it was higher than $8.0(\mathrm{Me}=8.0)$ with an average value of $9.36 \pm 8.55$. In the residents from small towns the number $\mathrm{M}$ was ranging from 1.0 to 21.0 , in half of them it was not higher than $8.0(\mathrm{Me}=8.0)$ and the average value was $8.70 \pm 5.65$. The lowest values of the number of missed teeth were found in patients living in large cities. The number $\mathrm{M}$ in this group was in the range between 0 and 25.0, in half of them it did not exceed 5.0 $(\mathrm{Me}=5.0)$, and the average value was $5.98 \pm 5.88$. An analysis of multiple comparison showed that statistically significant differences in $\mathrm{M}$ values occur between the patients - the residents of large cities and residents of small towns and between the studied respondents living in big cities and living in the countryside.

The reason for reporting to the dentist has also a statistically significant impact on the values of $\mathrm{M}$ (Kruskal-Wallis test $\mathrm{H}=13.28 ; \mathrm{p}=0.0013$ ). The patients who reported for a check-up 
visit had a lower number of missing teeth, the $M$ value in them was in the range of 0 to 22.0. In half of the respondents it was not higher than $4.0(\mathrm{Me}=4.0)$ and the mean was 5.55 \pm 5.74 . In patients reporting due to a toothache, the $M$ value was in the range $0-28.0$, in half of them the $M$ value did not exceed 5.0 $(\mathrm{Me}=5.0)$, and the average value was $7.62 \pm 8.01$. The highest $M$ values were observed in patients who reported to the dentist because of the loss of filling. For them, the number of missed teeth was in the range 1.0-23.0. In half of the patients it was not lower than $8.0(\mathrm{Me}=8.00$, and the average $\mathrm{M}$ value in this group of patients was $9.28 \pm 6.10$. Multiple comparisons test confirmed statistically significant differences in the $M$ value between patients reporting to the check-up visits and those who report with a toothache.

In the study group of patients it was showed that the number of fillings in the teeth (F) was in the range of 0 and 21.0. In half of them the F value was not higher than $11.0(\mathrm{Me}=11.0)$ and the average value was $10.59 \pm 5.42$. There were no statistically significant differences in the number of fillings in women and men (Mann-Whitney test $\mathrm{Z}=0.98 ; \mathrm{p}=0.33$ ). In women, the number of fillings was $0-21.0$, in half of them it was not higher than $10.0(\mathrm{Me}=10.0)$, and the average was $10.27 \pm 5.74$. In turn, the $\mathrm{F}$ value in men was ranging from 0 to 20.0 , in half of them it was not higher than $12.0(\mathrm{Me}=12.0)$ and the average was $11.05 \pm 4.92$.

The age of the patients had no statistically significant effect on the number of current fillings in the teeth (test for Spearman's rank correlation coefficient $\mathrm{R}=-0.15 ; \mathrm{p}=0.058$ ).

The impact of the place of residence on the number of fillings was statistically significant. The highest values were observed in $\mathrm{F}$ value in patients living in large cities. In this group, the number $F$ was ranging from 0 to 21.0, in half of them it was not higher than $12.0(\mathrm{Me}=12.0)$, with an average $11.46 \pm 5.38$. In the rural inhabitants, the number of fillings was ranging from 0 to 19.0. In half of the patients it was not higher than $7.0(\mathrm{Me}=7.0)$ and the average was $7.64 \pm 5.48$. In case of the respondents living in small towns, the $\mathrm{F}$ value was ranging from 2.0 to 15.0 , in half of them it did not exceed $10.0(\mathrm{Me}=10.0)$, and the average number of fillings was $9.55 \pm 4.08$. Based on the multiple comparisons test, statistically significant differences in the $\mathrm{F}$ value were found between patients living in big cities and patients living in rural areas.

The reason for visiting the dentist also had a statistically significant effect on the number of fillings (Kruskal-Wallis test $\mathrm{H}=6.32 ; \mathrm{p}=0.043$ ). The highest $\mathrm{F}$ values were recorded in people who reported for a check-up visit. The $\mathrm{F}$ value in this group ranged from 0 to 21.0, in half of the respondents it was not higher than $12.0(\mathrm{Me}=12.0)$ and the average value was $11.56 \pm 5.17$. In patients who reported due to the loss of filling the number $F$ was in the range of 1.0 to 20.0. In half of them, it was not higher than $10.0(\mathrm{Me}=10.0)$, with an average of $9.69 \pm 5.82$. Patients, who reported because of a toothache, had from 0 to 17.0 fillings. In half of them the $F$ value was not higher than $10.0(\mathrm{Me}=10.0)$, and the average was $8.93 \pm 5.15$.

The frequency of decay in the study group of patients was $100.0 \%(\mathrm{n}=154)$.

The DMF index ranged from 2.0 to 32.0. In half of the respondents it was not higher than $21.0(\mathrm{Me}=21.0)$, and the average value was $21.18 \pm 5.02$. For statistical analysis of the DMF index, parametric tests were used because DMF variable has a normal distribution. Caries intensity in the group of women surveyed was ranging from 2.0 to 32.0 . In half of the women it was not higher than $23.0(\mathrm{Me}=23.0)$ with the average value $-22.13 \pm 5.07$. In turn, the DMF index in men was ranging between 9.0 and 32.0. In half of the respondents it was not higher than $19.0(\mathrm{Me}=19.0)$ and the average value was $19.80 \pm 4.67$. Statistical analysis showed that the intensity of caries in women was significantly higher compared to men (Student t test $\mathrm{t}=-2.89, \mathrm{df}=152, \mathrm{p}=0.004$ ).

When using the Pearson correlation coefficient it was found that in the study group the value of DMF index increases with age $(\mathrm{r}=0.52 ; \mathrm{p}=0.0001)$. There is a positive average power correlation. Based on the determined regression line: $\mathrm{DMF}=0.40+0.49 *$ age, it can be said that with increasing age, each year the DMF index will increase by an average value 0.49 .

Patients' place of residence had no statistically significant effect on the DMF index (univariate ANOVA analysis $\mathrm{F}=0.78$; $\mathrm{p}=0.46$ ). However, the differences between the DMF value of patients who live in large cities $(\mathrm{DMF}=20.86)$ and the value of the DMF index in the rural population $(\mathrm{DMF}=22.12)$ can be observed. In small towns, the value of DMF index was 21.75.

In the respondents reporting to the dentist because of the loss of filling the value of the DMF index was 22.79, whereas of those reporting because of a toothache -21.69 . The lowest values of the DMF index were in patients who regularly reported to the control visits and amounted to 20.28 . The observed differences are statistically significant.

\section{DISCUSSION}

Our study confirms that women are the predominant group of patients visiting the dental clinic (59.09\%). Similar regularity was observed among the inhabitants of Cracow [8]. In other studies carried out in Cracow in the years 2005-2006, 20062010 and in 2008, and in the years 2013-2014, it was also found that women were more likely to visit dentists $[6,9,10]$. Also, epidemiological studies evaluating the oral health of the Polish population, which was conducted in the first decade of the twenty-first century, indicate that women are more likely than men to report at the dentist [5,11-13].

In determining the dental health behaviors of the Polish population in the framework of "A month of totally healthy smile" project in 2003 it was found that the largest group of patients reporting to the dentist lived in the countryside, and the least numerous - those who lived in big cities [12]. In the past several years in Poland, it has been observed that the inhabitants of big cities are the largest group visiting the dental clinic $[6,7,10,14]$, similarly as in our study $(70.78 \%)$, which is understandable at least because of the location of the dental clinic.

In the older group of patients than in our study - 65-74 years of age, toothache is the main reason for which patients report to the dentist [15], as it was the case in other previously published studies [16]. In case of patients reporting to the dental clinic in Lublin, toothache was the least likely reason given $(18.83 \%)$, which seems to be a positive phenomenon.

The available literature indicates that the need for surgical treatment (tooth extraction) may be the main reason for visiting the dentist $[6,10]$. However, in the case of our research it has not been analyzed. In addition, other authors reported the willingness for conservative treatment, including placing of a filling after the loss, as the most frequent cause of visits to the dentist $[9,12,14]$. In the present research it represented 
the second most common cause of visiting a dental clinic $(25.32 \%)$.

The present study does not assess the relationship between the place of residence and reason for visiting the dentist. Nevertheless, it is worth noting that under the Minister of Health project "Monitoring of the stats of oral health of Polish population in the years 2013-2015" it has been shown that patients living in large cities, report to the dentist mainly because of tooth pain, and patients coming from small towns - in order to control the teeth [4].

The intensity of dental caries confirmed in our study, expressed by the DMF index, is similar to the DMF index, which was found by assessing oral health of Poles ten years ago [17], whereby a higher value was confirmed in the DMF index of patients living in rural areas. In turn, the results of studies evaluating the oral health problems of the adult population of the province of Lodz (2012) showed that the value of the DMF index was higher in urban residents [5]. The similarity of the present research and the research center of Lodz consists in the fact that intensity of caries is higher in men than in women. The number of teeth affected by decay is higher among rural residents. The number of missed teeth is the largest in the rural population and higher in men than in women; more women have complete dentition; the number of fillings is higher in large cities residents than in the rural population; the frequency of caries is $100 \%$. Also, the results obtained in the research program of the Minister of Health in the period 2013-2015 and the studies from the years 1998-2009, show that patients coming from the big cities, and the women have more retained teeth, which is confirmed by our research as well $[4,10]$.

The above-mentioned studies in the Lodz region show that $35 \%$ of patients benefited from prosthetic restorations [5], which is a result similar to the results obtained in the present study $(38.96 \%)$. At the same time it should be noted that the group of patients from Lublin were people aged 35-54 years, whereas those patients from Lodz are in the age group 35-44 years.

\section{CONCLUSION}

Dental caries is still a major health problem in Polish population aged 35-44. It happens in Poland, even though the number of dentists is one of the highest in Europe [2], when there is a possibility of obtaining prophylactic benefits, treatment and rehabilitation, reimbursed by the NHF and for a fee. Poor oral health of the adult population in Poland is not the result of poor access to dental care, but due to the low health awareness of society. This requires launching a large-scale dental educational campaigns and prevention among adult Polish citizens, especially in rural areas [3-7]. Reducing the incidence and severity of dental caries and maintaining the greatest number of natural teeth will allow saving normal functions of chewing, thus contributing to improving the quality of life of adults.

\section{REFERENCES}

1. Chmielewska D, Stania M. Jakość życia zależna od stanu jamy ustnej u dorosłych. Twój Prz Stomatol. 2014;9:52-4, 58.

2. Minister Zdrowia. Monitorowanie stanu zdrowia jamy ustnej populacji polskiej w latach 2013-2015. [http://docplayer.pl/35359-Minister-zdrowia-monitorowanie-stanu-zdrowia-jamy-ustnej-populacji-polskiej-wlatach-2013-2015.htmlProgram na lata 2013-2015]. Access: 30.09.2016.

3. Kubić-Filiks B, Rosiak J, Szalewski L, et al. Socio-medical analysis of patients aged 0-6 years reporting to the dentist. Pol J Public Health. 2016;126:24-7.

4. Minister Zdrowia. Ocena stanu zdrowia jamy ustnej i jego uwarunkowań w populacji polskiej w wieku 35-44 i 65-74 lat. Badania epidemiologiczne wykonane w 2013 roku w ramach programu polityki zdrowotnej pn.: „Monitorowania stanu zdrowia jamy ustnej populacji polskiej w latach 2013-2015". [http://www.mz.gov.pl/zdrowie-i-profilaktyka/programy-zdrowotne/wykaz-programow/monitorowanie-stanu-zdrowia-jamy-ustnejpopulacji-polskiej-w-latach-2013-2015/]. Access: 07.10.2016.

5. Hilt A, Rybarczyk-Townsend E, Lubowiedzka-Gontarek B, WochnaSobańska M. Problemy zdrowotne jamy ustnej 35-44-letnich mieszkańców województwa łódzkiego. Przegl Epidemiol. 2012;66:133-8.

6. Novák P, Grzegocki M, Ryba B, et al. Oral health status and dental treatment needs of patients of the University Dental Clinic in Cracow in the period 2006-2010. J Stoma. 2013;66:485-93.

7. Gaszyńska E, Wierzbicka M, Marczak M, Szatko F. Thirty years of evolution of oral health behaviours and dental caries in urban and rural areas in Poland. Ann Agric Environ Med. 2014;21:557-61.

8. Łysek R, Polak M, Szafraniec K, et al. Socioeconomic status, health behaviours and oral health in adult urban population of Krakow. Dent Med Probl. 2016;53:66-77.

9. Michalak E, Łoboda J, Chomyszyn-Gajewska M. Reasons for patients' visit to dental clinics in Cracow in the years 2005-2006 and 2013-2014. Przegl Epidemiol. 2015;69:787-94.

10. Pytko-Polończyk J, Loster WB. Lecznicze potrzeby stomatologiczne pacjentów zgłaszających się do Uniwersyteckiej Kliniki Stomatologicznej w Krakowie w roku 2008. Implantoprotet. 2009;10:48-51.

11. Jodkowska E. Stan uzębienia dorosłych mieszkańców polski w latach 1998-2009. Przegl Epidemiol. 2010;64:571-6.

12. Borysewicz-Lewicka M, Wochna-Sobańska M. Stomatologiczne zachowania prozdrowotne ludności Polski w świetle badań epidemiologicznych wykonanych w roku $2003 \mathrm{w}$ ramach programu „Miesiąc totalnie zdrowego uśmiechu". Czas Stomatol. 2007;60:377-83.

13. Iwanicka-Frankowska E, Wierzbicka M, Pierzynowska E, Kępa J. Stan przyzębia i potrzeby profilaktyczno-lecznicze grupy osób dorosłych z regionu Warszawy. Nowa Stomatol. 2003;3:148-51.

14. Pawlik A. Aktualny stan zdrowia jamy ustnej Polaków. Twój Prz Stomatol. 2010;11:84-6, 88 .

15. Konopka T, Dembowska E, Pietruska M, et al. Periodontal status and selected parameters of oral condition of Poles aged from 65 to 74 years. Przegl Epidemiol. 2015;69:537-42.

16. Gracz L, Świderska J. Społeczne i ekonomiczne uwarunkowania podejmowania przez pacjentów leczenia stomatologicznego. Hygeia Public Health. 2011;46:77-82.

17. Ziętek M. Zdrowie jamy ustnej Polaków. Czas Stomatol. 2005;58:388-91.

\section{Corresponding author}

Prof dr hab. n. med. Jolanta Szymańska

Chair and Department of Paedodontics, Medical University of Lublin

7 Karmelicka Str., 20-081 Lublin, Poland

E-mail: szymanska.lublin@gmail.com 